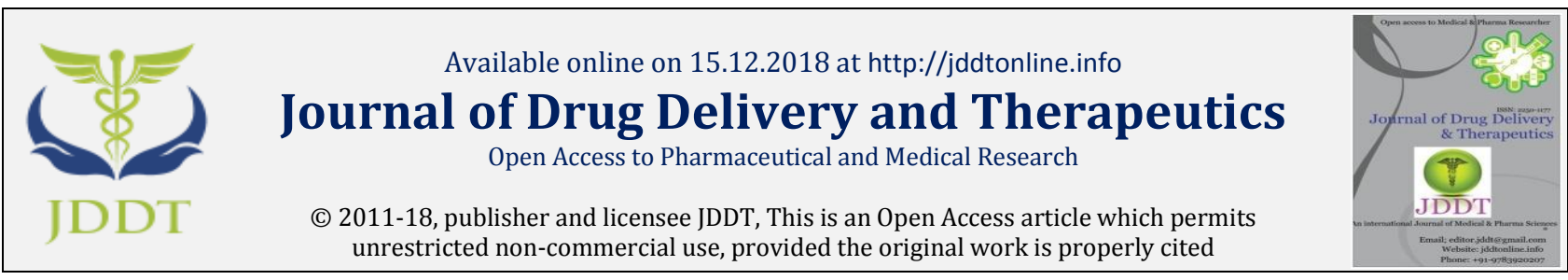

Open 2 Access

Review Article

\title{
A brief review of some important medicinal plants used in the treatment of asthma
}

\section{Arshu P Patel, M. Siddaiah}

Department of Pharmacy, Bhagwant Univercity, Shikar road, Ajmer, Rajasthan. India

\begin{abstract}
Asthma is a common disease that is rising in prevalence worldwide with the highest prevalence in industrialized countries. Asthma affects about 300 million people worldwide and it has been estimated that a further 100 million will be affected by 2025 . Ayurveda, Siddha, Unani and Folk (Tribal) medicines are the major systems of indigenous medicines. Over three-quarters of the world population relies mainly on plants and plant extracts for health care. Unlike many diseases, which can be attributed to the life style of modern man, asthma is an ancient illness. There are number of medicinal plants have been reported for antihistaminic/anti-asthmatic activities like Achyranthes aspera, Tephrosia purpurea, Dolichos lablab, Eclipta alba, Jasminum sambac, Balanites aegyptiaca, Viscum album, Tridex procumbens, Glycyrrhiza glabra and Cassia fistula. Present review is focused on used of medicinal plants for treatment of asthama. It is suggested that formulation and patent of the reported medicinal plants is mandatory for further use against asthma and if possible, clinical trials should be done of these plants for their appropriate use.
\end{abstract}

Keywords: Medicinal plants, Asthma, Mast cells, Antihistaminic.

Article Info: Received 15 Oct, 2018; Review Completed 27 Nov 2018; Accepted 29 Nov 2018; Available online 15 Dec 2018

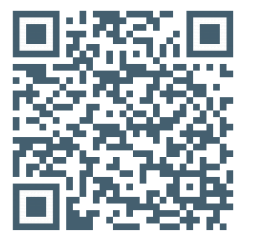

Cite this article as:

Patel AP, Siddaiah M, A brief review of some important medicinal plants used in the treatment of asthma, Journal of Drug Delivery and Therapeutics. 2018; 8(6-s):347-349 DOI: http://dx.doi.org/10.22270/jddt.v8i6-s.2087

*Address for Correspondence:

Arshu P Patel, Department of Pharmacy, Bhagwant Univercity, Shikar road, Ajmer, Rajasthan. India

\section{INTRODUCTION}

Herbs are staging a comeback and herbal 'renaissance' is happening all over the globe. The herbal products today symbolize safety in contrast to the synthetics that are regarded as unsafe to human and environment ${ }^{1}$. Although herbs had been priced for their medicinal, flavouring and aromatic qualities for centuries; the synthetic products of the modern age surpassed their importance, for a while. However, the blind dependence on synthetics is over and people are returning to the naturals with hope of safety and security. Over three-quarters of the world population relies mainly on plants and plant extracts for health care. More than $30 \%$ of the entire plant species ${ }^{2}$, at one time or other was used for medicinal purposes. It has been estimated that in developed countries such as United States, plant drugs constitute as much as $25 \%$ of the total drugs, while in fast developing countries such as China and India, the contribution is as much as $80 \%$. Thus, the economic importance of medicinal plants is much more to countries such as India than to rest of the world ${ }^{3}$. These countries provide two third of the plants used in modern system of medicine and the health care system of rural population depend on indigenous systems of medicine. Ayurveda, Siddha, Unani and Folk (tribal) medicines are the major systems of indigenous medicines. Among these systems, Ayurveda is most developed and widely practiced in India. ${ }^{4}$
Asthma is a disease of the human respiratory system in which the airways constrict and become narrow, often in response to a "trigger" such as exposure to an allergen, cold air, exercise, or emotional stress ${ }^{5}$. Asthma affects $7 \%$ of the total population ${ }^{6-7}$ and approx 300 million worldwide ${ }^{8}$. During attacks (exacerbations), the smooth muscle cells in the bronchi constrict, and the airways become inflammed and swollen. Breathing becomes difficult. Asthma causes 4,000 deaths a year in the U.S. Attacks can be prevented by avoiding triggering factors and by drug treatment. ${ }^{9}$

The modern day's peoples think asthma as a disease is so powerful that it is difficult to imagine person with asthma to live normal healthy life ${ }^{10}$. During past decades, Once English physicians Thomas Willis and Sir John Floyer began arguing that asthma was different from other breathing disorders and is the same from person to person. They mentioned that asthma, as a specific form of disordered breathing, must be treated differently from other forms of breathlessness cases. But in current scenario, doctors and clinician believed that asthma is a disease which had a specific set of causes, clinical consequences, and need special requirements for treatment, despite the diversity of individual experiences. ${ }^{11-12}$

Asthma can be classified into 2 stages: the steady-state of chronic asthma, and the acute state of an acute asthma exacerbation. Patient shows different symptoms 
depending on what state the patient is in. Common symptoms include: nighttime coughing, shortness of breath with exertion but no dyspnea at rest, a chronic 'throatclearing' type cough, and complaints of a tight feeling in the chest. Severity often correlates to an increase in intensity of symptoms. Symptoms can worsen gradually and rather insidiously, up to the point of an acute exacerbation of asthma. It is a common misconception that wheezing is common in patients with asthma-some never wheeze, and their disease may be confused with another chronic obstructive pulmonary disease such as emphysema or chronic bronchitis. ${ }^{6}$

Asthma mat be caused by verity of factors depending from environmental to genetic ${ }^{13}$ which can influence how severe asthma is and how well it responds to medication. ${ }^{14}$

\section{Stimuli}

$\checkmark \quad$ Allergens from nature, typically inhaled, which include waste from common household pests, the house dust mite and cockroach, as well as grass pollen, mold spores, and pet epithelial cells. ${ }^{15}$

$\checkmark$ Indoor air pollution from volatile organic compounds, including perfumes and perfumed products. ${ }^{15}$

$\checkmark$ Medications, including aspirin,16 $\beta$-adrenergic antagonists (beta blockers). ${ }^{17}$

$\checkmark \quad$ Use of fossil fuel related allergenic air pollution, such as ozone, smog, summer smog, nitrogen dioxide, and sulfur dioxide. ${ }^{8}$

$\checkmark$ Early childhood infections, especially viral upper respiratory tract infections. 18

$\checkmark \quad$ Psychological stress and cold weather. ${ }^{19}$

\section{Some traditional plants with antiasthmatic potential:}

\section{Aerva lanta Linn (Amaranthaceae).}

Aerva lanta (A. lanta) is an erect or prostrate herbaceous common wayside weed which is recognized by its white axillary bunches of small woolly flowers. It is abundant on the plains in the warmer parts of India. Ethanol extract of aerial parts of A. lanata at $100 \mathrm{mg} / \mathrm{mL}$ in the isolated goat tracheal chain preparation model and 30 and $60 \mathrm{mg} / \mathrm{kg}$ doses orally in clonidine-induced catalepsy and mast cell degranulation in mice possesses antiasthmatic activity. ${ }^{20}$

\section{Ageratum conyzoides:}

L. Ageratum conyzoides (A. conyzoides) is an erect, herbaceous annual plant from the family Asteraceae (Compositae), native to tropical America, but with a distribution range in tropical and subtropical areas around the world. Hydroalcoholic extract of leaves of A. conyzoides at doses of 250, 500 and $1000 \mathrm{mg} / \mathrm{kg}$ shows antihistaminic activity by inhibiting clonidine induced catalepsy in mice. ${ }^{21}$

\section{Asystasia gangetica (Acanthaceae):}

Asystasia gangetica (A. gangetica) is used in many parts of Nigeria for the management of asthma. Akah, et al. evaluated hexane, ethylacetate, and methanol extracts of the leaves of A. gangetica for antiasthmatic activity using guinea pig trachea; rat stomach strip; guinea pig ileal preparation and egg albumin-induced acute inflammation. The results indicated that the extracts did not exhibit contractile or relaxant activity in isolated tissue preparations; however, they inhibited the contraction evoked by spasmogens. ${ }^{22}$

\section{Ficus bengalensis Linn (Moraceae):}

Ficus bengalensisis (F. bengalensis) is a very large tree reaching about $30 \mathrm{~m}$ high and sending down many aerial roots from the branches. Ethyl acetate, ethanol and aqueous extracts as well as fractions isolated from aqueous extract of $\mathrm{F}$. bengalensis bark possesses antihistaminic activity by inhibiting clonidine induced catalepsy in mice at dose $50 \mathrm{mg} / \mathrm{kg}$. These activities may be due to presence of flavonoids. ${ }^{23-24}$

\section{Piper betel Linn:}

Piper betel is traditionally used to cure cough, cold, pruritis, asthma and rheumatism. Ethanol and aqueous extract of leaves at doses 100 and $200 \mathrm{mg} / \mathrm{kg}$ possesses antiasthmatic activity on histamine induced bronchoconstriction in guinea pig and histamine induced dose dependent contraction of guinea pig tracheal chain and isolated guinea pig ileum preparation. ${ }^{25}$

\section{Lantana camara (Verbenaceae):}

Lantana camara is one such pantropical weed which is affecting ecosystem, and causing biodiversity loss at greater extent. It is a shrub that belongs to the family of Verbenaceae. Lantana camara is one of the notorious weeds causing dramatic and apparently irreversible degradation of natural communities in India. It is highly invasive and currently occupies a large percentage of the vegetation cover wherever it was introduced. Its growth poses a threat to other biodiversity. The species is native of Central and South America and the Caribbean with geographical expansion between $35^{\circ} \mathrm{N}$ and $35^{\circ} \mathrm{S} .{ }^{26}$ Lantana camara has several therapeutic uses, mainly as herbal medicine ${ }^{27-29}$. Plant extracts are used for treatment of cancers, chicken pox, measles, asthma, ulcers, swellings, eczema, tumors, high blood pressure, bilious fevers, catarrhal infections, tetanus, rheumatism, malaria and atoxy of abdominal viscera ${ }^{30}$. It is further reported that verbacoside, a compound isolated from lantana extract has been demonstrated to possess anti-microbial immunosuppressive and anti tumour activities. Use of lantana oil in treatment of skin itches and as an antiseptic for wounds and externally for leprosy and scabies is also reported. ${ }^{31}$

\section{Argemone mexicana Linn (Papaveraceae):}

Argemone mexicana known as Ghamoyais an exotic weed indigenous in South America, but has widespread distribution in many tropical and sub-tropical countries including West Africa. It is considered as an important medicinal plant in India. The yellow juice, which exudes when the plant is injured, has found usage as traditional medicine in India for dropsy, jaundice, ophthalmia, scabies and cutaneous infections. Its various parts have been used in chronic skin diseases, emetic, expectorant, demulcent and diuretic, while its seeds and seed oil have been used for the treatment of dysentery, ulcers, asthma and other intestinal infections. ${ }^{32}$

\section{Datura stramonium Linn (Solanaceae):}

Datura stramonium is a wild-growing plant belonging to the Solanaceae family, is widely distributed and easily accessible worldwide. It contains a variety of toxic tropane alkaloids such as atropine, hyoscamine, and scopolamine and has been used in Ayurveda for curing various ailments like ulcers, wounds, inflammation, rheumatism, gout, 
sciatica, bruises, swellings, fever, asthma, bronchitis and toothache. Previous studies have revealed pharmacological effects of this plant, however, complete information regarding its pharmacology, toxicity, ethnobotany and phytochemistry still remain. ${ }^{33}$

\section{Plumbago zeylanica Linn (Plumbaginaceae):}

Plumbago zeylanica is commonly known as white chitraka, belonging to the family plumbaginaceae. It is distributed as a weed throughout the tropical and subtropical countries of the world. It is a perennial subscandent shrub, growing throughout India, especially in Bengal, Uttar Pradesh, Kerala, Andhra Pradesh, Karnataka and Sri Lanka in most places. Traditionally it is used as a stimulant, digestant, expectorant, laxative, abortifacient and also in the treatment of muscular pain and rheumatic disease. ${ }^{34}$

\section{REFERENCES}

1. Patel S., Saxena N., Saxena R.C., Arya N., Saxena R. and M. Tharani. Evaluation of anti-asthmatic activity of Glycyrrhiza glabra. Biosciences, Biotechnology Research Asia. 2007; 6 (2):761-766.

2. Patel S., Tenguria R.K., Mishra P. K. Pharmacological and ethnomedicinal studies of Tridex procumbens Linn. (Family: Compositae) for anti-asthmatic activities. Environmental Conservation Journal. 2005; 6 (1):27-31.

3. Sharma S, Soni K. K., Saxena R. C. Pharmacology of an Ayurvedic Indian medicinal plant for mast cell degranulation activity. Biomedical \& Pharmacology Journal. 2008; 1 (2):42932

4. Urmaliya S., Bharti M.D., Jain V., Agnihotri V.K., Saxena R.C., Baghel U. S., Saxena R. Isolation of saponin from Tridex procumbens (Asteraceae). Intern. J. Chem. Sci, 2011; 9(3):1281-1284.

5. http://www.sciencedaily.com/articles/a/asthma.htm. Accessed on Jan 132009.

6. http://www.merck.com/mmhe/sec04/ch044/ch044a.html. Accessed on Jan 132009.

7. http://www.merck.com/mmhe/sec04/ch048/ch048a.html. Accessed on Jan 162009.

8. H. Christopher and N. Fanta. Asthma. The New England Journal of Medicine. March 2009; 360(10):1002-1014.

9. http://en.wikipedia.org/wiki/Asthma. Accessed on Jan 18 2009.

10. www.nlm.nih.gov/hmd/breath/.../Asthma/asthmaframe.htm l. Accessed on Jan 62009.

11. Yawn B. P. Factors accounting for asthma variability, achieving optimal symptom control for individual patients. Primary Care Respiratory Journal, 2008; 17(3):138-147.

12. Homer A., Boushey Jr. M.D., David B., Corry M.D., John V., Fahy M.D., Esteban G., Burchard M.D., Prescott G., Woodruff M.D., Saunders "Asthma". Mason: Murray \& Nadel's Textbook of Respiratory Medicine, $20054^{\text {th }}$ Edition, Elsevier.

13. Longmore, M., Genes, environments, development and asthma: a reappraisal. European Respiratory Journal. 2007; 29(1):179-84.

14. Choudhry S., Seibold M. A., Borrell B. A. Dissecting complex diseases in complex populations: asthma in latino americans. Proceedings of the American Thoracic Society. 2007; 4(3):226-33.

15. Adkinson N. F., Bochner B. S., Busse W. W., Holgate S. T., Lemanske R. F., SimonsF. E. R., Middleton's Allergy Principles \& Practice. Chapter 33: "Indoor Allergens." Elsevier (2008).

16. Maurya S. D., Aggarwal S., Dhakar R. C., Tilak V. K., Soni U., Liposomes As A Drug Delivery Carrier - A Review, IRJP, 2010; 1(1):43-50.

17. John M., Miller P., Douglas Z. Braunwald's Heart Disease: A Textbook of Cardiovascular Medicine, 8th ed. "Chapter 33 Therapy for Cardiac Arrhythmias." Elsevier. (2007).

18. Adkinson N. F., Bochner B. S., Busse W., Holgate S. T., Lemanske R. F., SimonsF. E. R., Middleton's Allergy Principles

\section{CONCLUSION}

Chronic bronchial asthma diseases, bronchial hyper responsiveness etc. are the leading health problem in worldwide, with secretarial most important reason of bereavement in developing countries. As from above explanation, it is clearly identified that medicinal plants are evaluated and their useful parts are reported based on their effectiveness in bronchial asthma and their clarification also shows their prospective beneficial effect of this diseases. So, in recent times more efforts should be focused towards the useful scientific evaluation for their protection, usefulness and effectiveness of this disease. In this review article, it has been prepared to accumulate the reported anti asthmatic plants in the field of Ayurveda.

\& Practice. "Chapter 42 - Epidemiology of Asthma and Allergic Diseases - Risk factors for Asthma".. Elsevier (2008).

19. Chen E., Miller G. E., Stress and inflammation in exacerbations of asthma. Brain Behaviour And Immunity, 2007; 21(8):993-9.

20. Tote M. V., Mahire N. B., Jain A. P., Bose S., Undale V. R., Bhosale A. V. Effect of Ageratum conyzoides Linn on clonidine and haloperidol induced catalepsy in mice. Pharmacologyonline, 2009; 2:186-194.

21. Bhalke R. D., Gosavi S. A., Antistress and antiallergic effect of Argemone mexicana stem in asthma, Arch. Pharm Sci Res, 2009; 1(1):127-129.

22. Akah P. A., Ezike A. C., Nwafor S. V., Okoli C. O., Enwerem N M. Evaluation of the anti-asthmatic property of Asystasia gangetica leaf extracts. J Ethnopharmacol, 2003; 89:25-36.

23. Taur D. J., Nirmal S. A., Patil R. Y. Effect of various extracts of Ficus bengalensis bark on clonidine and haloperidol-induced catalepsy in mice. Pharmacologyonline, 2007; 3:470-477.

24. Taur D. J., Patil R. Y. Effect of bio-fractions isolated from Ficus bengalensis bark on clonidine induced catalepsy. J Pharmacy Research, 2009; 2(11):1676-1677.

25. Jawale N. M., Shewale A. B., Nerkar G. S., Patil V.R. Evalution of antihistaminic activity of leaves of Piper betel Linn. Pharmacologyonline, 2009; 3:966-977.

26. Sharma G.P., Raghubanshi A.S. and Singh J.S. Lantana invasion: An overview. Weed Biology Management. 2005; 5:157-167.

27. Kohli R.K., Batish D.R., Singh H.P. and Dogra K.S. Status, invasiveness and environmental threats of three tropical American invasive weeds (Parthenium hysterophorus L., Ageratum conyzoides L., Lantana camara L.) in India. Biological Invasion. 2006; 8:1501-1510.

28. Dogra K.S., Kohli R.K. and Sood S.K. An assessment and impact of three invasive species in the Shivalik hills of Himachal Pradesh, India. International Journal of Biodiversity and Conservation. 2009; 1(1):4-10.

29. Dhakar R.C., Maurya S. D., Pooniya B.K., Bairwa N., Gupta M. Moringa: The herbal gold to combat malnutrition, Chronicles of Young Scientists, 2011; 2 (3):119-123.

30. Sharma O. P., Sharma S., Pattabhi V., Mahato S. B. and Sharma P. D. A Review of the Hepatotoxic Plant. Lantana camara. Journal of Scientific \& Industrial Research. 2007; 37:313-352.

31. Begum S., Wahab A. and Siddiqui B. S. Pentacyclic triterpenoids from the aerial parts of Lantana camara. Chemical and Pharmaceutical Bulletin. 2000; 51:134-137.

32. Brahmachari G., Gorai D., Roy R. Argemone mexicana: chemical and pharmacological aspects. Revista Brasileira de Farmacognosia. 2013; 23(3):559-67.

33. Gaire B. P., Subedi L. A review on the pharmacological and toxicological aspects of Datura stramonium L. Journal of integrative medicine. 2013; 11(2):73-9.

34. Rana A. C., Plumbago Z. A Phytopharmacological review. International Journal of Pharmaceutical Sciences and Research. 2011; 2(2):247. 